\title{
Miranda
}

Revue pluridisciplinaire du monde anglophone /

Multidisciplinary peer-reviewed journal on the English-

speaking world

$5 \mid 2011$

South and Race / Staging Mobility in the United States

\section{Laughing at the United States}

\section{Eve Bantman-Masum}

\section{OpenEdition}

\section{Journals}

Electronic version

URL: http://journals.openedition.org/miranda/2362

DOI: $10.4000 /$ miranda.2362

ISSN: 2108-6559

\section{Publisher}

Université Toulouse - Jean Jaurès

\section{Electronic reference}

Eve Bantman-Masum, "Laughing at the United States", Miranda [Online], 5 | 2011, Online since 29 November 2011, connection on 16 February 2021. URL: http://journals.openedition.org/miranda/2362 ; DOI: https://doi.org/10.4000/miranda.2362

\section{This text was automatically generated on 16 February 2021.}

\section{$\Theta \Theta \Theta \Theta$}

Miranda is licensed under a Creative Commons Attribution-NonCommercial-NoDerivatives 4.0 International License. 


\title{
Laughing at the United States
}

\author{
Eve Bantman-Masum
}

\section{Introduction}

1 Karl Marx once wrote that "history repeats itself, first as tragedy, second as farce". This is a lesson that Mexicans seem to have learnt well insofar as their relationship to the United States is concerned. In the decades that followed its Independence from Spain, Mexico suffered so many forms of U.S. encroachment that resisting Northern influence became a central element in Mexican nationalism. As a consequence, Mexicans also developed a peculiar sense of political humor and irony regarding U.S.-Mexico relations. But this ubiquitous aspect of Mexican political culture has received very little academic attention. The aim of this article is to explore Mexican humor-particularly popular jokes and comical representations-on the United States and the American people ${ }^{1}$ and to make sense of the abundance of light-hearted, witty, popular comments on Mexicans and Americans. This supplement to the existing works on North American relations examines the connection between representations of race and politics, documenting the impact of essentialist descriptions of U.S. citizens on political beliefs and practices in Mexico.

2 The kind of humor we shall explore undoubtedly verges on racism: it can be both crude and offensive. Humorists make fun of how Americans behave and often target American leaders; worse, they even trivialize 9/11. We do not endorse the views reported here, and neither do most Mexicans. Much of the material under study comes from empirical data collected in Mexico between 2002 and 2006 and illustrates the views of left-wing activists who strongly resent U.S. leadership and influence. More importantly, Mexican humor is also notoriously graphic and vulgar, hinging on macabre when it comes to politics. This love of macabre is rooted in cultural habits in Mexico. Owing to centuries of political instability and human tragedy, Mexicans have been practicing immoral humor for decades. Considered from this angle, joking about $9 / 11$ is the same as laughing at death, revolutions, epidemics, etc (Giasson). This kind of 
humor is clearly immoral, but should not be understood as an expression of deep-felt hatred for the United States. It serves other functions that will be analyzed here.

Obviously, humor is a benign form of criticism compared to terrorism, even if jokes on America and Americans are depressingly negative, even racist. While U.S. jokes on Mexicans are under constant academic scrutiny, humor is conspicuously absent from the literature on anti-Americanism, in spite of the fact that Mexicans routinely crack up over all aspects of U.S. society, culture, and politics. Experts trying to assess potential threats to national security generally conclude that Mexican antiAmericanism is relatively benign (MacPherson), with post-9/11 contributions often ignoring Mexico altogether (Judt and Lacorne; O'Connor and Griffiths; Schlapentokh et al.). Studies on perceptions of the United States and U.S. citizens in Mexico-a better source of information on our topic-have produced a body of evidence on the existence of essentialist clichés and patterns of representation of the Other in Mexico (Merrill; Meyer; Morris, 2000 and 2005). General studies have also noted that Mexicans simultaneously love and hate the United States (Ganster and Pacheco; Raat; Ricard), highlighting the ambivalent co-existence of Americanization and Anti-Americanism in Mexico.

The few existing studies on Mexican humor view it as a social ritual. Schmidt, writing before the fall of the PRI-the post-revolutionary authoritarian party that ruled Mexico for 70 years-maintained that jokes helped Mexicans survive political oppression. Before him, Limon had shown that vulgar forms of macho banter were practiced in a context of deep political and economic alienation. More recently, Torres presented humor as the weapon of the weak, a form of subaltern discourse. The last two writers view humor (irony for Torres and banter for Limon) as a social ritual performed by poor, exploited workers. Humor is therefore very political in Mexico, and even more so when one considers jokes on the United States. Indeed, ever since 1847, Mexican leaders have systematically claimed to be defending Mexican integrity against U.S. encroachments. However, they practiced a highly ambivalent form of nationalism, preaching Mexican resistance to the United States and simultaneously encouraging U.S. influence in Mexico. Discourse and policies were harmonized after the North American Free Trade Agreement of 1994 (Nafta), leading to closer relations between the two powers. But although Mexican nationalism is no longer officially anti-American, Mexican nationalists still privately believe in and practice resistance to the United States. As we shall see, jokes on the United States tend to be very critical of official proclamations, and encourage nationalism as well as individual opposition to closer U.S.-Mexico relations.

Expounding on previous studies, we shall first discuss stereotypes on Americans and the binary opposition between Mexicans and Gringos to show how humorists subvert all clichés. Jokes take up the official discourse on "Poor Mexico, so far from God and so Close to the United States" and then playfully reinterpret tales of Good and Evil to condemn corruption and weakness among Mexicans in their dealings with powerful, profit-oriented Americans. A powerful tool in the hands of opposition leaders and dissenters, humor on U.S.-Mexico interactions is part of what we shall call "everyday anti-Americanism", popular practices of resistance to U.S. influence. Anti-American humor can therefore be considered as a form of social rite. Examples of political debates will introduce readers to anti-American humor in use. Our findings confirm what many before us have described-the existence of clichés on North American 
culture and civilization, resentment against U.S. interventionism, economic might, and push for free trade-but also illustrate how popular interpretations have moved beyond the love-hate paradigm.

\section{Essentializing difference, challenging the balance of power}

6 To begin with, most jokes on the United States do not solely criticize the United States. Instead, they equally dwell on the shortcomings of Mexicans. In doing so, humorists are elaborating on preconceived notions of the differences between the two countries that have been hotly debated by Mexican intellectuals ever since Independence in 1820 . There is indeed a protracted history of comparison between the two peoples, the Mexican and the North American. For example, one of the early critics of national characters, Lorenzo de Zavala, who later abandoned Mexico to become the vicepresident of Texas, elaborated on these clichés on the two nations. To some extent, his views have shaped many prevailing ideas about North-Americanness:

An industrious people, active, reflexive, circumspect, religious amidst many sects, tolerant, miser, free, proud and persevering. Mexicans are light-hearted, lazy, intolerant, generous, even bountiful, belligerent, superstitious, ignorant and hostile to dominions of all kinds. (Carballo 51) ${ }^{2}$

7 In the 1820s, Zavala portrayed Mexican boisterous irrationality and then the frugalness of Americans, and its corollary, affluence. Since then, most Mexican intellectuals have, at some point, compared in similar terms the national characters of the two people, thereby transforming highly subjective observations into classic, influential essentialist clichés. Early descriptions and comparisons of national characters tell us that Mexicans form a mediocre people and praise the industriousness and genius of North America. After the traumatic defeat of 1847 , the description of U.S. character was transformed to include new elements: greed, materialism, imperialist tendencies, lack of morals and culture. Repetition led Mexicans to believe that this comparison was self-explanatory when in fact it was premised on prejudice. In addition, essentialist clichés are highly ambivalent, at once praising and criticizing North Americans. They are even less consistent when it comes to Mexicans who are systematically described as deeply mediocre people. Notorious samples of such propaganda can be found in Mexican textbooks that have, ever since the second half of the nineteen ${ }^{\text {th }}$ century, encouraged patriots to remember North American encroachments (Vazquez et al.; Covo; Gilbert; Roldan) and act accordingly.

8 Mexican humorists typically elaborate on contradictions to highlight the inconsistencies contained in a political discourse that simultaneously glorifies Mexican resistance to the United States and encourages closer relations to the United States. Instead of lamenting Mexican inferiority and extolling North American superiority, the following joke typically celebrates Mexican shortcomings and ridicules North American greatness. In the Mexican version, the American tourist speaks broken Spanish:

A group of gringo tourists is touring the Mexican countryside. In one village, they notice a Mexican small farmer resting in the shade under a tree, enjoying his nap. One of the gringos joins him there to start a conversation:

Hello amigo, howaryou?

Great, thank you. Just relaxing.

You tell me: why you not working on your lands? 
What for?

For get more output and sell more.

What for?

Like this for make more money and buy animals.

What for?

For animals get reproduction and sell and make more money.

What for?

For have nice house and live at ease and relax.

What for amigo? Ain't I relaxing just now?

9 The lazy Mexican in the joke embodies all the defects listed by Zavala and others in their depictions of Mexican inferiority. But here, the clever Mexican beats the hardworking Gringo. This suggests that Mexican underdevelopment is proof of the nation's superior nature: why work when you can have it all without working? The fact that the visiting Gringo displays such a poor command of Spanish certainly bespeaks, in the eyes of a Mexican nationalist, his limited genius. Like others, this joke tends to subvert existing hierarchies. Asymmetry of power between the two countries has resulted in what many view as poor treatment of Mexican immigrants in the United States, and an open-door policy for Gringo tourists in Mexico. A century of mass migration to the United States has convinced a great number of Mexicans that they would never receive fair treatment in the United States. At the same time, tourism to Mexico has developed, with millions of North Americans now vacationing in the country. Mocking Gringos in Mexico who ridicule undocumented Mexicans in the United States is one way of showing defiance and resistance.

Similarly, the following joke turns official Mexican rhetoric about the two countries on its head: "If Mexico hadn't been there, Walt Disney would surely have invented it" (author's translation). The joke lampoons an idea that is immensely popular in Mexico -the classic opposition between Mexico's cultural heritage and North American cultural barrenness. Mexicans use the expression Gringolandia to refer to the United States (and to Americanized spaces in Mexico, like Cancun): the name is derived from two words, Gringo (now an almost neutral synonym for Americans) and the name of U.S. leisure park Disneyland, suggesting that the U.S. is superficial, big business but no real culture. Mexico is the butt of the joke here, a place so ridiculous that the Gringos could actually showcase it. More subtly, the joke suggests that Mexicans are not culturally authentic. Instead, they are under the influence of North American mass culture: they are agringados. The word does not translate as "Americanized": Mexican nationalism ruled that to ape the Gringo was to cease to be a Mexican; to be agringado is therefore to have debased yourself to embrace the American Way of Life, to have renounced civilization and become a traitor. Even as it teases Mexican nationalists, this joke is also directed at North Americans. It suggests they need Mexico, a point that is rarely admitted in the North American public sphere but which underpins the popular analysis of U.S.-Mexico relations in Mexico.

11 Interestingly, many jokes on the United States tend to be about Mexican politicians too. As the saying goes, "You're Mexican if you blame the PRI for practically everything, and the United States for everything else" (author's translation). Schmidt mentions one joke that circulated during George Bush Senior's Gulf War, and which might seem opaque to outsiders: "Salinas sent two destroyers to the Middle East: Echeverria and López Portillo" (Schmidt, author's translation). Echeverria and Lopez Portillo are two PRI politicians: the first is commonly held responsible for the 1968 student massacre at Tlatelolco while Lopez Portillo is blamed for starting the debt crisis which plagued the 
Mexican economy in the 1980s. Salinas-widely believed to have won the 1988 presidential election by fraud-ruled the country between 1988 and 1994. He was decidedly pro-American and signed NAFTA into law. Having destroyed Mexican hopes for autonomy and trampled upon the nationalist ambition to resist U.S. hegemony, these leaders could therefore be assimilated by many to "destroyers". At a more subtle level, the joke offers one last twist: receiving help from such inept leaders may deliver unexpected results, such as an American defeat in what was viewed by many as yet another imperialist scramble for oil. Generally speaking, the idea that Mexican politicians are dangerously incompetent is the starting point of many jokes similar to this one:

Mexico's President made an announcement yesterday:

"I have got good news and bad news for the country. The good news is that we've repaid all the money we owed the United States. The bad news is that we must leave the country in 15 days."

While many Mexicans are convinced that U.S. leaders are still hoping to lay their hands on more Mexican land (and natural resources), they also believe that Mexico is governed by a corrupt clique ready to sell Mexico away: entregar el pais a los gringos. There is even a name for this state of mind (entreguismo) and for those who practice it

(los entreguistas). Mexican politicians are portrayed as betraying the country by serving U.S. national interest, and leaving Mexicans with nothing at all. The idea that Mexican politicians are incapable of sustaining the population is so popular that you will find it reprinted in many books. A leading Mexican sociologist remarked in an article published shortly after Nafta came into effect that:

If the Mexican state had been in charge of the development of the United States during the nineteenth century, it would probably have persecuted the grain farmers until it had taken everything away from them, scattered them and converted them into beggars. (Zermeño, 205)

Jokes that seem very critical of the United States often target, as we have just seen, local elites rather than the U.S.

Mexican jokes on the U.S. and Americans can nevertheless be very offensive. Even if it was immoral to do so, Mexicans used to joke a lot about 9/11 in the years that followed the attacks on the World Trade Center. There are many reasons why Mexicans reacted in such an unpredictable way. Since anti-Americanism is no longer the official ideology of the Mexico State in Mexico, it is now growing out of control. Mexican authorities no longer monitor anti-Americanism, and remarks about the United States have become less tame, less politically correct, and therefore more impertinent. What was a clearly articulated set of preconceived clichés on American-ness to be printed in magazines and textbooks has now retreated to the private realm. In addition, laughing at tragedies is culturally accepted, even encouraged to a certain extent, in Mexico. So the graver the situation is, the funnier the jokes will be: the fact that it might be immoral to laugh about something only makes it more pleasurable.

15 Considering all this, 9/11 was a natural target for Mexican humorists, especially because of the War on Terror. Sadly, the response to 9/11-War-led many Mexicans to believe that the U.S. had returned to imperialism. Mexicans clearly opposed the War on Terror, with government declining to participate and refusing to send troops to Iraq or elsewhere. With the War on Terror, the idea that Americans are prepotente became very popular. Officially, the word is used to describe someone who is at once arrogant, domineering, and overbearing. But Prepotencia is also a political concept whereby 
Americans are made responsible for Imperialism. Gringos prepotentes tend to think very highly of themselves, believe they are always right, and impose their views and lines of conduct on others. With 9/11 and the War on Terror, Prepotencia became a hot issue, with humorists highlighting U.S. weakness in every sense of the word.

Living in Mexico in the months that followed 9/11, you would constantly be told jokes similar to this one: "Mexico and the United States are playing chess. Who's the winner? Mexico, because the United States are missing two towers". Jokes like this one do not satirize American character, nor celebrate the deaths of Americans. They overstate what the terrorist attacks seemed to prove at the time: that the United States was no longer invincible, that it could be defeated, that it was vulnerable. The fact that it was cruel to laugh about the loss of innocent lives was ignored, except by those who feared for their loved ones living in the United States, or those who sympathized with the victims for personal reasons (including one informant who mentioned that those who had died in the towers were not decision-makers but workers, including many immigrants). Still, similar jokes were silently conquering the Mexican public sphere, to the point where $9 / 11$ could be casually mentioned.

One of the most popular jokes about 9/11 tells the story of how Bin Laden had originally chosen to blow up the Torre Latinoamericana, a Mexico City skyscraper built in 1956. But no sooner had his hitmen set foot in Mexico that a customs officer had stolen their bags. When the Arabs hired a cab to the airport, they were hijacked by the driver. After paying a heavy ransom, they were released only to catch Moctezuma's revenge (food poisoning). Convinced that no terrorist attack could ever be launched in this desmadre [mess], they finally decided to cross over to the other side, which took them weeks because of bad traffic and difficulties with the border patrol. Many versions of the joke circulated in 2002: one said that the terrorists were never able to launch the attack because they had been robbed and were too poor to buy a plane ticket; another explained that they had given up trying upon realizing that Mexicans kept erratic business hours, and that it would be impossible to commit mass murder in Mexico by hitting a deserted office building with a plane. Each time, $9 / 11$ is only a pretext to laugh about corruption and crime in Mexico. These jokes also ridicule the ambitions of Mexico's modernizing elite who built the Torre Latinoamericana,-a miniature version of America's breathtaking skyscrapers, a lone monument towering over the low-rising colonial center of town and the sprawling, underdeveloped metropolis. At a deeper level, the joke says that Mexico is led by a bunch of terrorists anyway, competing to ruin the lives of ordinary Mexicans who heroically manage to conduct their daily lives in spite of crime and extreme conditions of living. Simultaneously, it lists all the reasons why millions of Mexicans have decided to leave their homeland and migrate to the United States. The joke is another example of the humorous quality inherent to popular nationalism: it praises the heroism of Mexicans who are too strong to be threatened by Arab terrorists; inversely, more perversely, the joke implies that Americans are less heroic, less resilient too.

\section{Anti-American rites: redefining the relationship between South and North}

But humor is not static. And beyond what it means, it is equally important to understand how it is practiced. Joking serves first and foremost a social purpose: to 
show friends a good time and reinforce group cohesion. Political jokes serve a dual purpose: they strengthen ties among a political community and guarantee speech effectiveness. Because it is spontaneous, humor is a mood, as well as a statement. The jokes reported here first circulated by word of mouth. During our fieldwork, informants used to spontaneously offer witty comments on the U.S.-Mexico relationship. Something about my research interest (studying the relationship between Mexicans and the United States) prompted them to make a statement, to show the rest of the world that they were not fools. This humor illustrates the popular, as opposed to the official view on geopolitics. Part of the fieldwork was conducted in Chiapas, among a left-wing community that had set out to defend Mexico against both U.S. ambitions and Mexican corruption. These activists had settled in Chiapas (southern Mexico) to support the Ejercito Zapatista de Liberación Nacional (EZLN, or EZ). The Zapatistas, as they are now called, stole the show away from Nafta when they emerged in Chiapas on January 1st 1994 . They were soon joined by Leftists from across the globe, among whom many Americans, who set out to challenge U.S.-led globalization.

The Zapatistas put the idea of Mexican resistance to the North back on the political agenda. Speaking from the Southern state of Chiapas, they revitalized anti-American nationalism from a racialist perspective: indigenous Mexicans have since been presented as the natural alternative to U.S. capitalism, spearheading popular efforts to rescue Mexico from neo-liberalism. Although this is never the most central element in their discourse, Zapatistas clearly oppose the pure, indigenous South to the racist, decadent North. They have revived essentialist clichés on national character to garner support for their cause: defending the rights of Indigenous Mexicans from both government and U.S. intervention. Here, Mexicans are defined as racial opposites of Anglo-Americans, an idea that had haunted intellectuals of the first half of the twentieth century, from José Vasconcelos to Samuel Ramos. However, in spite of this discouraging focus on race, post-1994 discussions of North-South relations have also asserted the need for new interpretations and new policies.

The EZLN has made ample use of humor to ridicule Mexican leaders and globalization, Mexican politicians have established such a poor record that alternative politicians do not want to sound like them. As a consequence, humor has gradually and undoubtedly become an essential feature of alternative political discourses. Political humor was brought to a new level with Marcos, one of the Zapatistas' most popular speakers, who has the ability to turn political speech-usually couched in stern, technical terms-into something pleasurable to the ear. This gift was crucial in garnering support for the EZLN in Mexico and beyond. Reflecting upon their communication and use of the Internet, Oliver Froehling noted how Marcos' fantastic sense of humor, particularly his conversations with a beetle called Durito, "have helped to coalesce a diverse network of followers and have guaranteed ongoing international visibility" (Froehling 297). What made Marcos' style particularly appealing was "his knowledge of global culture, ... his diverse styles, humor, self-criticisms, references to literature and indigenous culture, and access to other social movements" (ibid, 290). In her analysis of the writings of the Subcommandante Marcos, Nathalie Blasco concurs that humor played a central part in securing widespread adherence to the Zapatista analysis of Mexican politics (Blasco 79). Both Froelhing and Blasco cite texts where Marcos quips about Americans, the United States, and entreguismo. 
21 From an empirical point of view, laughing at the United States is crucial in garnering support for the cause. Humorous speeches are far more efficient than rational explanations of politics, especially when one is dealing with activists. The day George W. Bush was reelected, an alternative technological institute based in San Cristobal de las Casas (Chiapas) held a research seminar on Immanuel Wallerstein in order to "study his work and see how it could help us in solving our contemporary political problems". The research seminar was designed to help community organizers in Chiapas deepen their understanding of the global political situation: all the people who attended the seminar belonged to a leftist organization and were decidedly pro-Zapatista. A Mexico City professor had been invited to discuss the balance of power between Mexico and the United States. He supported John Kerry, but his words fell upon dead ears. People were talking loudly instead of listening, even when he mentioned American greed, superpower, and Mexican corruption. Nothing worked.

At another conference organized by Zapatista supporters and left-wing activists at the national university (UNAM) in Mexico City in 2003, the same topics had elicited a radically different response from the audience. The speaker had started by cracking a few jokes about 9/11 and Zedillo-Salinas' successor, who presided over the 1995 peso crisis: "9/11 has created a New World Order. Even Zedillo is talking geopolitics now! [Laughter] If his politics are as good as his economics... [Laughter]." ${ }^{3}$ Like all good jokes about the United States, this one is about Mexico, its corrupt elite, and U.S. prepotencia. The jokes that followed ran along the same line as the ones we have discussedAmerican greed, elite incompetence, and their unexpected consequences. The speaker's humor celebrated the genius of humble Mexicans, playing upon the discrepancies between official and alternative conceptions of nationalism in Mexico and the United States:

I'm still hoping that one day we will get our best president in a long time, not here, but in the United States [Laughter]. Because if things remain the way they are now, all of us millions of Mexicans are going to cross over to the other side! [Laughter]. Not to mention other Latin American peoples! If the United States wish to go harakiri, then they should just push on with neoliberalism! We are going to help them fill the demographic gap left by 9/11! (op.cit, author's translation)

People were laughing so loud the speaker had to pause and wait for them to catch their breath. But when calm returned, he had their full attention and they proved wholeheartedly receptive to his central idea, which was very similar to that of the Chiapas speaker: Mexicans need to adopt a more global perspective and nuance their understanding of the United States. He discussed Tobin and the Tobin tax for ten minutes, actually praising him for his work but declaring at the end that his theory catered to the needs of developed states, not those of developing countries. ${ }^{4}$ And because the speaker was funny, even hilarious sometimes, he managed to capture everybody's attention for over forty minutes, and to raise serious issues in the process. When he explained how the United States was verging on bankruptcy, the listeners clung to every word he said and nodded at the idea that America needed Mexico, and Mexican oil, to get back on its feet:

Oil-and we all know that in Mexico, oil is a national security priority [Laughter]costs 3 dollars. They say that it is no business. They say that it is a curse to have oil! But if it is a curse, then what do the Gringos want it for?! [Laughter]. Isn't it strange how the Gringos always seem to want the things we don't want?! I for one don't know of any Gringo buying worthless things! [Laughter] (op.cit, author's translation) 
These sentences were uttered with a different accent, reminiscent of the kind of Spanish spoken in small-town Mexico. This is the voice of common sense, that of ordinary Mexicans questioning top-down decision made by Mexican Presidents: the Mexican nation knows that the people in power are giving the oil away and betraying the nation. One might view these jokes as interludes to maintain the listeners' attention. But they also speak of a different way of doing politics; the speaker does not pretend he is the only knowledgeable person in the room. On the contrary, he extends his authority to all those who share his beliefs. He reminds those present of what they know and confirms their superior understanding of the treacherousness of all elites. The opening statement on oil being a national security priority is more daring because it also encourages the listeners to reconsider classic nationalist formulations. Instead of focusing on nationalist preconception about oil-the symbol of Mexican resistance to the United States ever since it was nationalized in 1938-, the speaker wanted to look at the wider picture; contrary to many who simply lampoon all politicians, he hoped to create a shift in paradigms. This is exactly what the Chiapas speaker had hoped to do at the Immanuel Wallerstein seminar; but he had failed at it because he was taking things too seriously. The attitude of the UNAM speaker is also emblematic of a certain democratic mindset: rulers get chided for their incompetence and the opinions of rankand-file citizens are taken into consideration. In the following extract, the oppressed become the witty heroes of a political tale in which Mexican and American leaders feature only as idiots:

It's easy [for the United States] to attack Somalia, Haiti, Iraq, Fox! [Laughter] But France! They're boycotting French Fries! [Laughter] I don't even worry about the United States anymore: I worry about their gastronomy. They are going to end up without Mexican enchiladas, no French wines, no Chinese food, no-with the Vatican's blessing-Arab food! [Laughter]. They're just going to end up with bretzels [laughter]. But then you need to know how to eat those! [Everyone cracks up] (op.cit. author's translation)

Instead of condemning America's wars, the speaker chose to ridicule them, and by adding Vicente Fox's name to the list (Mexico's president at the time) he simultaneously reminded his Mexican audience of the political weakness of recent rulers who have supported the United States unconditionally. The joke plays upon two ideas, one old and one new. Traditionally, Mexicans consider Mexican food unpalatable, yet another proof of America's lack of cultural greatness. The three types of food mentioned here (French, Chinese and Arabic food) are among the most popular foreign cuisines in Mexico (which was briefly ruled by France in the 1860s, received a lot of Chinese workers before the Revolution; Arab tacos are a standard feature of the Mexican shopping street). The idea discussed here is that the United States is so weakand unpopular-that no one wants to fight its War on Terror. In fact it is so weak that it cannot even banish those who resist it. Mexicans should no longer focus on the United States because they are about to collapse (an idea that the speaker had developed at length earlier on, arguing that the country was laboring under debt and that power was being transferred elsewhere). The finale is an allusion to the incident where George W. Bush almost choked on a bretzel. All in all, the joke draws a very bleak picture of the United States, ruled by someone who cannot eat properly, who bullies weaker nations into turning over their natural resources, and yet proves unable to rally allies after 9/11. 
This particular sequence signals that some changes are taking place in the way Mexicans consider the United States. Surreptitiously, Mexicans have adopted a new way of looking at their relationship to the United States. For a long time, opposition leaders were content with just denouncing the unhealthy relationship between the U.S. and Mexican governments and clamoring for a return to nationalism and resistance to dependence. But the jokes we have just reviewed do not just elaborate on classic views of the U.S. in Mexico. They are also introducing new elements into the equation: elitebashing, praise for ordinary Mexicans, irony toward ideology, to name just a few. These jokes reflect an intimate relationship to the United States and great disillusionment with nationalism among the masses. The solution, it seems, is no longer to either resist or give in. The balance of power between North and South needs to be reassessed, now that the United States is no longer all-powerful: Mexicans are ready for innovative policies. While they remain fond of essentialist clichés, they have considerably distanced themselves from the view that Mexicans can only be either superior or inferior to the American people.

Before concluding, one word about the deeper significance of anti-American humor in Mexico. Our analysis is premised on the idea that joking is a rite that strengthens ties among a political community of dissenters in Mexico. But laughing at Americans-and Mexican relations with the United States-is related to other forms of everyday resistance that seek to challenge the existing balance of power, such as ripping off tourists or complaining about gringos. Assessing the relevance of such practices at a national level is almost impossible because studies of anti-Americanism in Mexico have hardly investigated them at all. Clearly, most Mexicans are friends of the United States, even if many have at some point abused tourists, criticized North Americans or joked about them. Explaining why Mexicans-like many others-indulge in anti-Americanism can be traced down to specific U.S. policies and their disastrous consequences. But antiAmericanism also exists beyond politics and interactions, because it serves a crucial social function. Criticizing the United States and Americans partakes of a wider process of identity formation in Mexico. In a world where the United States has driven global standardization of business and culture, anti-Americanism is a very common form of nationalism. By resisting and challenging the U.S. model, Mexicans assert their right to exist independently, reclaim their national heritage, and defy leaders who failed to defend the national interest.

In Mexico, anti-American humor is the language of those who yearn for more political participation, people who feel trampled upon, with not even a government to stand up for them and uphold their ideals. While resistance to the United States used to be the official doctrine of the government, it is now the language of those who oppose those in power, particularly politicians in favor of economic liberalization and North American integration. Joking allows powerless patriots to ridicule Mexican corruption, and its corollary, dependence on the United States. One among many practices of everyday resistance, humor is redefining Mexican ideology, and particularly, popular attitudes toward the United States. Laughing at the United States is a demonstration of political seriousness, a proof that the people cannot be fooled.

Even if it has received very little academic attention, humor is therefore an important aspect of political culture in Mexico. It is a crucial component of the Mexican relationship to the United States. After all, one of the most popular descriptions of this relationship is an ironic saying attributed to nineteen ${ }^{\text {th }}$ century dictator Porfirio Diaz 
who famously quipped, "Poor Mexico, so far from God and so close to the United States". Most Mexicans adhere to this interpretation of history (Mexico has suffered from geographic proximity to the United States), and also to the irony behind it: Diaz was a dictator who promoted U.S. economic interests in Mexico at the expense of true development for Mexicans. But Poor Mexico must not be taken at face value: it is not simply an ironic assessment of the situation-defenseless Mexico falling prey to Yankee imperialism-but also, more importantly, a national symbol of ideological hypocrisy in a country where political leaders have encouraged anti-Americanism just as they created a pro-American environment.

Mexicans are now calling for alternatives: after all, they have come a long way since the nineteen ${ }^{\text {th }}$ century but they are still yearning for access to the world beyond the United States. The current wave of drug-related violence might reinforce the trend, with millions of citizens marching against policies inspired by the United States that have cracked hard on crime and made Mexico increasingly unsafe. In this context, humor on the United States is as vital as ever, maintaining tradition and yet voicing popular yearning for change. It soothes and supports rebellion against all dogmas. In the words of a Mexican author:

The involuntary humor of politicians is an endless source of material for newsmen and cartoonists around the world. Historians are irremediably leaving aside these fundamental moments of life. (Alatriste, author's translation)

31 For all these reasons, jokes on America and Americans should not be ignored by specialists of U.S.-Mexico relations because they provide a crucial insight into popular political culture. Similarly, material that documents popular beliefs and practices regarding the United States should be given center stage in the literature on antiAmericanism.

\section{BIBLIOGRAPHY}

Alatriste, Sealtiel. "Por qué no hay humor en la historia". Revista de la Universidad de México 4 (June 2004).

<http://www.revistadelauniversidad.unam.mx/0404/contenido.html>

Bantman-Masum, Eve. Unis contre les États-Unis ? EHESS, 2007.

Blasco, Nathalie. "L'humour dans les communiqués du sous-commandant Marcos : le contre-pied des pratiques ascétiques des révolutions marxistes (1994-2005)". In Humour et politique en Amérique latine/humor y política en América latina. Ed. Yves Aguila. Bordeaux : Presses Universitaires de Bordeaux, 2006. 43-80.

Carballo, Emmanuel. Que Pais Es Este? Los Estados Unidos y los gringos vistos por escritores mexicanos de los siglos XIX y XX. Conaculta: Sello Bermejo, 1996.

O'Connor, Brendon and Martin Griffiths (eds). The Rise of Anti-Americanism. London and NY : Routledge, 2006. 
Covo, Jacqueline. "L'Enjeu du manuel scolaire au Mexique : l'image des États-Unis”. In États-Unis Mexique Fascinations et Répulsions Réciproques. Ed. Serge Ricard. Paris: L'Harmattan, 1996.

Froehling, Oliver. "The Cyberspace” War of Ink and Internet in Chiapas in Mexico." Geographical Review 87.2 (April 1997): 291-307.

Ganster P. and M Mirando Pacheco (eds). Imagenes Recíprocas. La educación en las relaciones MéxicoEstados Unidos de América Quinta Reunion de universidades de México y Estados Unidos. Mexico : Amacalli Editores, 1991.

Giasson, Patrice. "Le Mexique populaire et les images tragiques. Sur les traces de l'artiste Nicolás De Jesús”. Images re-vues 5 (2008) 1 September 2008.

<http://imagesrevues.revues.org/337>

Gilbert, Dennis. "Rewriting History. Salinas, Zedillo and the 1992 Textbook Controversy.” Mexican Study-Estudios Mexicano 13:2 (Summer 1997): 271-298.

Judt, Tony and Denis Lacorne (eds). With Us or Against US. Studies in Global Anti-Americanism. New York: Palgrave MacMillan, 2005.

Limon, José. "Carne, carnales, and the Carnivalesque: Bakhtinian Batos, Disorder, and Narrative Discourses”. American Anthropologist 16:3 (Aug. 1989): 471-486.

McPherson, Alan. Yankee No! Anti-Americanism in U.S.-Latin American relations. Cambridge and London: Harvard University Press, 2003.

Merrill, John C. “The United States As Seen From Mexico." Journal of Inter-American Studies 5:1 (Jan. 1963): 53-66.

Meyer, Michael C. "Mexican Views on the United States". In twentieth century Mexico. Eds. Raat and Beezley. Lincoln: University of Nebraska Press, 1986. 286-300.

Morris, Stephen D. Gringolandia. Mexican Identiy and Perceptions of the United States. New York: Rowan and Littlefield, 2005.

---. "Exploring Mexican Images of the United States". Mexican Studies/Estudios Mexicanos 16:1 (Winter 2000): 105-139.

O'Connor, Brendon and Martin Griffiths (eds). The Rise of Anti-Americanism. London and NY: Routledge, 2006.

Raat, Dirk. Mexico and the United States. Ambivalent Vistas. Athens and London: University of Georgia Press, 1992.

Ramos, Samuel. El perfil del hombre y la cultura en México. México DF: UNAM, 1934.

Ricard, Serge (ed.) États-Unis Mexique Fascinations et Répulsions Réciproques. Paris : L'Harmattan, 1996.

Roldan, Vera. "Les origines de l'histoire nationale au Mexique. Les premiers manuels scolaires (1852-1894)." In Ecrire l'histoire de l'Amérique Latine XIXe-XXe siècles. Eds. Michel Bertrand et Richard Martin. Paris: CNRS Editions, 2001.

Schlapentokh, Vladimir, Joshuah Woods and Eric Shiraev. America, Sovereign Nation or Cowboy Nation. Aldershot: Ashgate Publishing, 2005.

Schmidt, Samuel. "Humor y política en México”. Revista Mexicana de Sociología LIV :1 (enero-marzo 1992) : 225-247. 
Torres, Gabriel. The Force of Irony. Power and the Everyday Life of Mexican Tomato Workers. New York: Berg, 1997.

Vasconcelos, José. The Cosmic Race: A Bilingual Edition. Baltimore: Johns Hopkins University Press, 1997.

Vazquez, Josefina, Tanck de Estrada, Staples et Arce Gurza. Ensayos sobre la historia de la educación en Mexico. 1981. México: Colmex, 1985.

Zermeño, Sergio. "Society and Politics in Contemporary Mexico". In Citizens of the Pyramid; Essays on Mexican Political Culture. Ed. W. Pansters. Amsterdam: Thela, 1997.

\section{NOTES}

1. For lack of adequate terms, we shall be referring to U.S. citizens as Americans, North Americans, or gringos-now a neutral expression. There is no English equivalent for the more specific Mexican term estadounidense.

2. My rendition of the original text: "Un pueblo laborioso, activo, reflexivo, circunspecto, religioso en medio la multiplicidad de sectas, tolerante, avaro, libre, orgulloso y perseverante. El mexicano es ligero, perezoso, intolerante, generoso y casi prodigo, vano, guerrero, supersticioso, ignorante y enemigo de todo yugo" (Carballo 1996). The book provides many examples of the comparison between Mexicans and Americans.

3. Author's translation of a recording of the conference, UNAM, 2003. All following quotes come from the same source.

4. The exact quote is, "We want our own economists who think in Latin American terms, not caricatures of economists who, like Stieglitz or Tobin, only make the system more acceptable. That's not what we want".

\section{ABSTRACTS}

Jokes on the United States and Americans are very popular in Mexico. Based on stereotypical representations of the Other, this brand of humor now supports a radical critique of North American relations. To Mexican humorists, the World Trade Center attacks and the War on Terror served as evidence of U.S. decline. This interpretation of events ridicules the unduly alliance between Mexican governments and U.S. leaders. But beyond politics, laughing at the United States also serves a social purpose, that of strengthening ties among Mexicans for whom resisting the United States is synonymous with gaining the right to exist independently.

Les blagues sur les États-Unis et les Américains sont très populaires au Mexique. Elles s'appuient sur des représentations essentialisées de l'Autre qui servent de support à une critique radicale de la politique interaméricaine. Les attentats du 11 septembre et la Guerre contre le Terrorisme ont notamment fourni aux humoristes mexicains une preuve du déclin de l'empire américain. Mais indépendamment des relations internationales, l'humour est également une pratique sociale, qui 
cimente les communautés politiques et renforce leur légitimité. Dans le contexte mexicain, l'humour anti-américain permet de mettre l'idéologie à distance, tout en affirmant son patriotisme, puisqu'en ironisant au sujet de la gouvernance nord-américaine, on affirme son autonomie et sa capacité de résistance.

\section{INDEX}

Keywords: anti-americanism, 9/11, humor, Mexico, United States, north-south relations, images, visions, ideology, zapatismo

Mots-clés: humour, Mexique, États-Unis, politique, représentations, idéologie, zapatisme, relations nord-sud, 11 septembre 2001

\section{AUTHORS}

\section{EVE BANTMAN-MASUM}

Maître de Conférences

Université Toulouse 2 - Le Mirail

bantman@univ-tlse2.fr 